\title{
Sun-shade variation in bamboo (Poaceae: Bambusoideae) leaves
}

\author{
Robert H. March and Lynn G. Clark
}

Department of Ecology, Evolution and Organismal Biology, 253 Bessey Hall, Iowa State University, Ames, IA 50011-1020 U.S.A.

E-mail:lgclark@iastate.edu

\begin{abstract}
The differential occurrence of fusoid cells in sun compared to shade leaves of three species of bamboo (Poaceae: Bambusoideae) was examined through leaf morphology and anatomy. Leaves grown in sun were consistently smaller and thicker and lacked fusoid cells, whereas leaves grown in shade were consistently larger, thinner, and had fusoid cells. These differences were also found between exterior and interior leaves within one individual of one of these three species. An infusion experiment using a fourth species indicated that light transmission increased dramatically as fusoid cells (or the spaces formed by their collapse) absorbed mineral oil. We propose that fusoid cells are a mechanism to trap and redistribute light more efficiently in shade leaves of bamboo and early-diverging grasses. This is the first report of leaf anatomical sunshade variation in bamboo leaves, but we emphasize the preliminary nature of our observations and the need for further study.
\end{abstract}

\section{Introduction}

That sun and shade leaves differ in a general suite of characteristics is well documented; only representative references are cited here as this is not intended to be an exhaustive review. Leaves grown in direct sunlight are usually smaller and thicker with closer vein spacing compared to shaded leaves that are larger and thinner with more widely separated veins (e.g., Wylie 1949, 1951, Esau 1977, Cui et al. 1991, Ashton \& Berlyn 1994, Yano \& Terashima 2004, Terashima et al. 2006). Epidermal layers, especially the adaxial epidermis, are thicker in sun leaves than in shade leaves. Photosynthetic and light absorption characteristics, including mesophyll surface area, chloroplast distribution, resistance to $\mathrm{CO}_{2}$ diffusion within the mesophyll, and rate of photosynthesis among others, also differ between sun and shade leaves (e.g., Nobel 1976, Boardman 1977, Lee et al. 1990, DeLucia et al. 1996, Terashima et al. 2001, Yano \& Terashima 2004, Terashima et al. 2006).

Sun-shade leaf variation has been documented in a wide range of plant taxa, primarily angiosperms (e.g., references cited above, mainly for woody dicots) but also gymnosperms (e.g., Korstian 1925, Tucker \& Emmingham 1977) and even 
pteridosperm fossils (Barbacka \& van Konijnenburg-van Cittert 1998). Reports of sunshade leaf variation within the grasses (Poaceae) confirm the same basic anatomical and physiological adaptations found in dicots (e.g., Slade 1970, Knapp \& Gilliam 1985). Sun-shade differences within the canopy of a single individual have also been documented (Wylie 1949).

Hsiao et al. (1996) reported significant genetic differentiation between sun and shade subpopulations of Yushania niitakayamensis (Yushan cane, a temperate woody bamboo) in Taiwan. They also noted a difference in height between the sun and shade plants of this species, with sun plants generally reaching $1 \mathrm{~m}$ tall and shade plants growing up to $5 \mathrm{~m}$ tall, and cited Chen (1992) for additional information on variation in growth form in this species. This is the only report of sun-shade variation in bamboos that we found.

Among grasses, bamboos (Bambusoideae), the three early-diverging lineages (Anomochlooideae, Pharoideae, and Puelioideae), and Streptogyna P. Beauv. (incertae sedis) possess a characteristic leaf blade anatomy featuring in the mesophyll large, cigar-shaped, thin-walled, apparently empty cells known as fusoid cells and lobed or invaginated chlorenchyma cells known as arm cells (Brandis 1907, Page 1947, Soderstrom et al. 1987, Judziewicz et al. 1999, Grass Phylogeny Working Group 2001). As seen in cross section, the long axis of the fusoid cells is parallel to the epidermal layers, and typically a fusoid cell extends more or less perpendicularly from each side of a bundle (abutting the bundle sheath directly) into the middle of the mesophyll (Judziewicz et al. 1999, figs 14 \& 15). Normally one layer of chlorenchyma cells is abaxial and one to three layers are adaxial to the fusoid cells (Page 1947, Judziewicz et al. 1999). As seen in leaf clearings, the fusoid cells are tightly packed in continuous longitudinal rows interrupted only by commissural veins (Judziewicz et al. 1999, fig. 16). The fusoid cells can occupy up to approximately $30 \%$ of the leaf blade volume (Clark 1991). Both Brandis (1907) and Page (1947) noted that the fusoid cells often (but not in all taxa) collapse, leaving large intercellular spaces.

Some taxa within Bambusoideae, however, are reported to lack fusoid cells. Among American woody bamboos, these include Apoclada McClure and Filgueirasia Guala (Guala 1995, 2003) and a few species of Chusquea Kunth (Clark 1986). The temperate woody genus Phyllostachys Sieb. \& Zucc. is described as usually lacking fusoid cells (Watson \& Dallwitz 1992 and onwards). Within Olyreae (herbaceous bamboos), Ekmanochloa A. Hitchc. and Mniochloa pulchella (Griseb.) Chase (Zuloaga et al. 1993), at least some species of Raddiella Swallen (Calderón \& Soderstrom 1967) and Parodiolyra ramosissima (Trin.) Soders. \& Zuloaga (Soderstrom \& Ellis 1987) lack fusoid cells. At least some of these taxa occur in more open habitats (e.g., high altitude grassland species of Chusquea) but their lack of fusoid cells has never been investigated in terms of correlation with habitat.

Although fusoid cells are a prominent feature of the leaves of bamboo and earlydiverging grasses, the possible function(s) of these cells remains unknown. Clark (1991) proposed that fusoid cells serve as reservoirs for $\mathrm{CO}_{2}$ from photorespiration. We have not found any other hypotheses as to the function of fusoid cells to date.

Preliminary observations of two species of woody bamboos, Yushania niitakayamensis and Chusquea culeou, which occur in both shaded forest understoreys and adjacent clearings and grasslands (Lin 1978, Chen 1989, Pearson et al. 1994), revealed morphological and anatomical variation between sun and shade leaves, especially with respect to the presence or absence of fusoid cells. In our studies, we also included 
Phyllostachys aurea (an Asian bamboo now widely cultivated) because of its putative lack of fusoid cells, and Bambusa longispiculata (another Asian bamboo often found in cultivation) because of its relatively large fusoid cells. We report our observations on sun-shade variation in bamboo leaves, with particular reference to the occurrence of fusoid cells, and propose a possible function for fusoid cells.

\section{Materials and Methods}

Plant Material. Yushania niitakayamensis and Chusquea culeou were collected in their natural habitats by March in Asia and by Clark in South America, respectively, as part of independent field work for systematic studies of each genus. Phyllostachys aurea and Bambusa longispiculata were cultivated in the R.W. Pohl Conservatory, Iowa State University (U.S.A.).

The following vouchers were used in this study:

Bambusa longispiculata Gamble ex Brandis. UNITED STATES. Iowa: Story Co., R.W. Pohl Conservatory, Bessey Hall, campus of Iowa State University, March 37 (ISC). Chusquea culeou E. Desv. CHILE. Malleco: Parque Nacional Nahuelbuta, next to the Centro de Administración, 1120 m, 10 Jan 1992, Clark et al. 974 (sun) (CONC, ISC, MO, SGO, US, VALD); Malleco: Parque Nacional Nahuelbuta, between the main bifurcation and the turnoff to El Aguila, 1210 m, 10 Jan 1992, Clark et al. 976 (shade) (CONC, ISC, MO, SGO, US, VALD). Phyllostachys aurea Carrière ex Riv. \& C. Riv. UNITED STATES. Iowa: Story Co., R.W. Pohl Conservatory, Bessey Hall, campus of Iowa State University, March 36 (sun and shade) (ISC). Yushania niitakayamensis (Hayata) Keng f. TAIWAN. Ilan: path to Nan Hu Ta Shan, timber cutting road \#810, c. $2 \mathrm{~km}$ E of highway, 2005 m, 26 Jun 1998, March 25 (shade) (A, ISC, K, MO, US); Nantou: c. 3 km N of Ho Huan Shan, 2845 m, 26 Jun 1998, March 27 (sun) (A, ISC, K, MO, US); Taoyuan: Lala Shan Forest Reserve, on saddle between Lala Shan and Taman Shan, toward Lala Shan $100 \mathrm{~m} \mathrm{~N}$ of fork in path to Taman Shan, 1860 m, 30 Jun 1998, March 29 (shade) (A, ISC, K, KUN, MO, US); Kaohsiung: c. $30 \mathrm{~m}$ above spring for Yenfeng Shelter on SE shoulder of Yu Shan, 3650 m, 5 Jul 1998, March 30 (sun) (A, ISC, K, KUN, MO, TAIF, US); Kaohsiung: c. $20 \mathrm{~m} \mathrm{NNW}$ of Yenfeng Shelter on saddle between Yu Shan and South Yu Shan Peaks, 3710 m, 6 Jul 1998, March 31 (sun) (A, ISC, K, MO, US); Chiayi: on trail from Tataka to Pai Yun Shan Station, $7 \mathrm{~km}$ from Tataka, $1.5 \mathrm{~km}$ from Pai Yun Shan, 3200 m, 6 Jul 1998, March 32 (shade) (A, ISC, K, MO, US); Chiayi: on trail from Tataka to Pai Yun Shan Station, c. $1.5 \mathrm{~km}$ from Tataka, where trail crosses $2790 \mathrm{~m}$, just above first set of switchbacks, 2790 m, 6 Jul 1998, March 33 (sun) (A, ISC, K, MO, US); Taichung: Anma Shan, just off approach road, 2850 m, 14 Jul 1998, March 34 (sun) (A, ISC, K, MO, US); Taichung: Anma Shan, near summit, 2944 m, 14 Jul 1998, March 35 (sun) (A, ISC, K, MO, US).

Paraffin Sections. Paraffin-embedded sections were prepared from foliage leaf blades taken from herbarium specimens ( $Y$. niitakaymensis and C. culeou) or from fresh leaves fixed directly in FAA ( $P$. aurea). Whole leaf blades from herbarium specimens were soaked in Pohl's solution (Pohl 1965) for at least seven days and then fixed for $24 \mathrm{hrs}$ in FAA. Pieces approximately $1 \mathrm{~cm}^{2}$ were taken from the mid-portions of the whole leaf blades and processed for embedding and sectioning. A total of 14 samples were prepared: two of $C$. culeou (one from each voucher), two of $P$. aurea (exterior and interior leaves from the same individual), and 10 of $Y$. niitakayamensis (two from March 30 and one from each of the eight other vouchers). 
Protocols for desilicification and dehydration followed Clark (1986). Leaf pieces were then bulk stained for one hour in 1\% safranin in 1:1 ethanol:xylene, and rinsed for one hour each in two changes of xylene before infiltration for two days each in 2:1 xylene:paraffin, 1:2 xylene:paraffin, and $100 \%$ paraffin at $60^{\circ} \mathrm{C}$. Samples were sectioned $10 \mu \mathrm{m}$ thick on a rotary microtome, mounted on glass slides and stained in safranin (40 min) and fast green (4 min) using standard procedures (Sass 1958, Berlyn \& Mikshe 1976).

Hand Sections. Hand sections were prepared from either fresh leaf material or leaves from herbarium specimens softened for a few minutes in Pohl's solution (Pohl 1965). Sections were cut using a single-edged razor blade and immediately mounted and stained in a solution of lactophenol and aniline blue (Sass 1958). A few leaves per voucher were checked for consistency of fusoid cell development using this method.

Leaf Infusion. A leaf infusion process (Woolley 1971) involving mineral oil, which has a refractive index close to that of plant cell walls, was performed on fresh leaves of Bambusa longispiculata to determine the effect of fusoid cells on the transmission of light. For the infusion, whole fresh foliage leaf blades were coated with mineral oil, placed adaxial side down on microscope slides, and observed from the abaxial side under low magnification with a compound microscope at regular intervals (approximately every 20 minutes) for several hours.

\section{Results}

Morphology. Sun-grown plants of both Y. niitakayamensis and C. culeou had shorter culms and smaller but relatively wider, lanceolate, foliage leaf blades compared with shade-grown plants (Fig. 1, Table 1). Likewise, foliage leaf blades of $P$. aurea grown in full sun were smaller, relatively wider and more lanceolate than those grown in the shade.

Table 1. Comparison of sun and shade morphology in Y. niitakayamensis, C. culeou and $P$. aurea.

\begin{tabular}{|c|l|l|l|l|l|}
\hline & $\begin{array}{l}\text { Plant } \\
\text { Height } \\
\mathbf{( m )}\end{array}$ & Leaf Shape & $\begin{array}{l}\text { Mean } \\
\text { Leaf } \\
\text { Length } \\
\mathbf{( m m )} \\
\mathbf{( n = 1 0 )}\end{array}$ & $\begin{array}{l}\text { Mean } \\
\text { Leaf } \\
\text { Width } \\
\mathbf{( m m}) \\
(\mathbf{n}=\mathbf{1 0})\end{array}$ & $\begin{array}{l}\text { Mean } \\
\text { Leaf } \\
\text { Length: } \\
\text { Width } \\
(\mathbf{n}=\mathbf{1 0})\end{array}$ \\
\hline Yushania niitakayamensis & & & & & \\
\hline Sun & $<0.8$ & lanceolate & 33 & 4.0 & 8.1 \\
\hline Shade & $1-6$ & linear & 104 & 7.2 & 14.3 \\
\hline Chusquea culeou & & & & & \\
\hline Sun & $1-1.5$ & lanceolate & 38 & 3.9 & 9.8 \\
\hline Shade & $2-3$ & linear & 80 & 5.6 & 14.3 \\
\hline Phyllostachys aurea & & & & & \\
\hline Sun & --- & lanceolate & 68 & 16 & 4.2 \\
\hline Shade & --- & $\begin{array}{l}\text { lanceolate and } \\
\text { linear }\end{array}$ & 107 & 17 & 6.1 \\
\hline
\end{tabular}




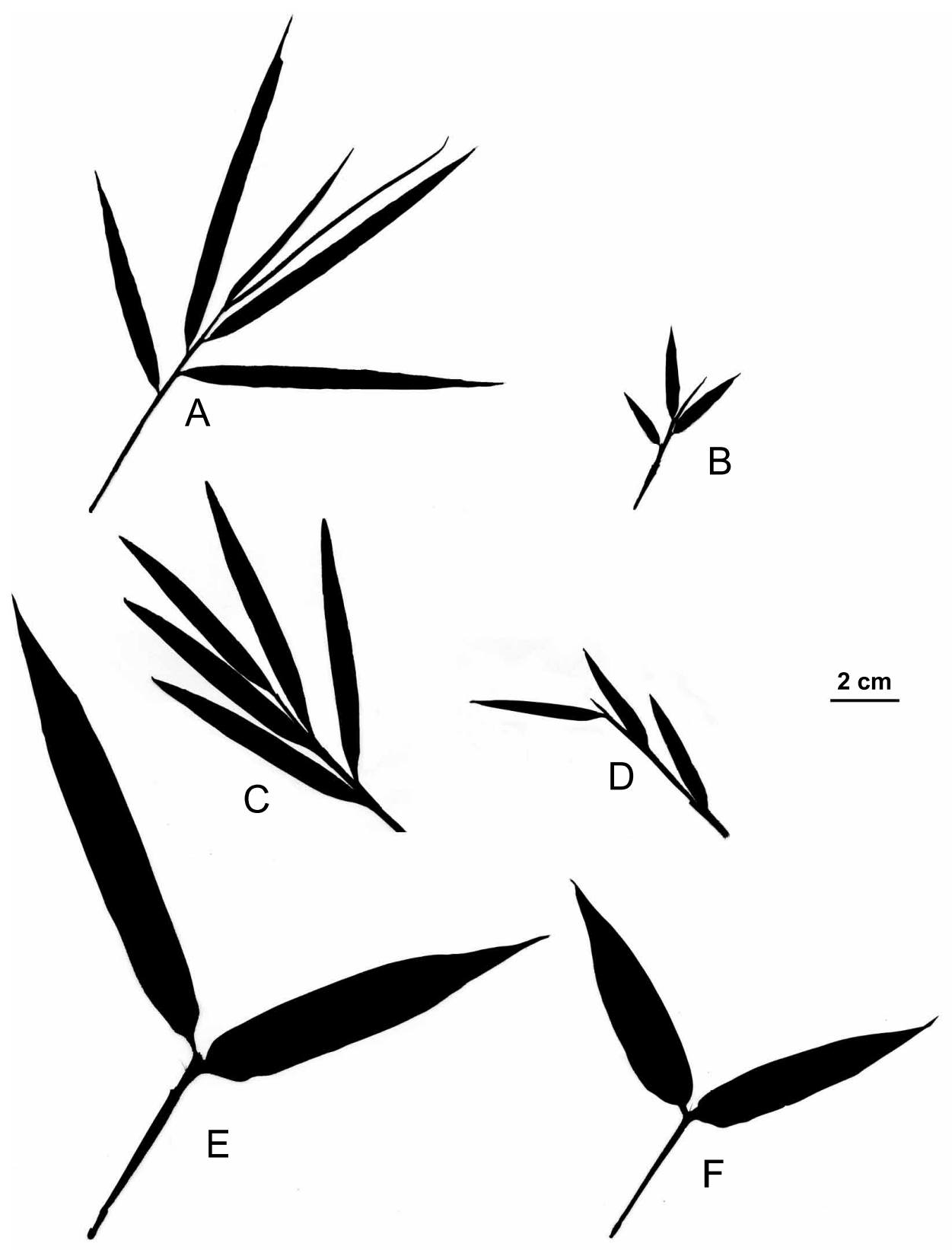

Fig. 1. Leaf silhouettes of Yushania niitakayamensis shade (A), sun (B); Chusquea culeou shade (C), sun (D); and Phyllostachys aurea shade (E), sun (F). 

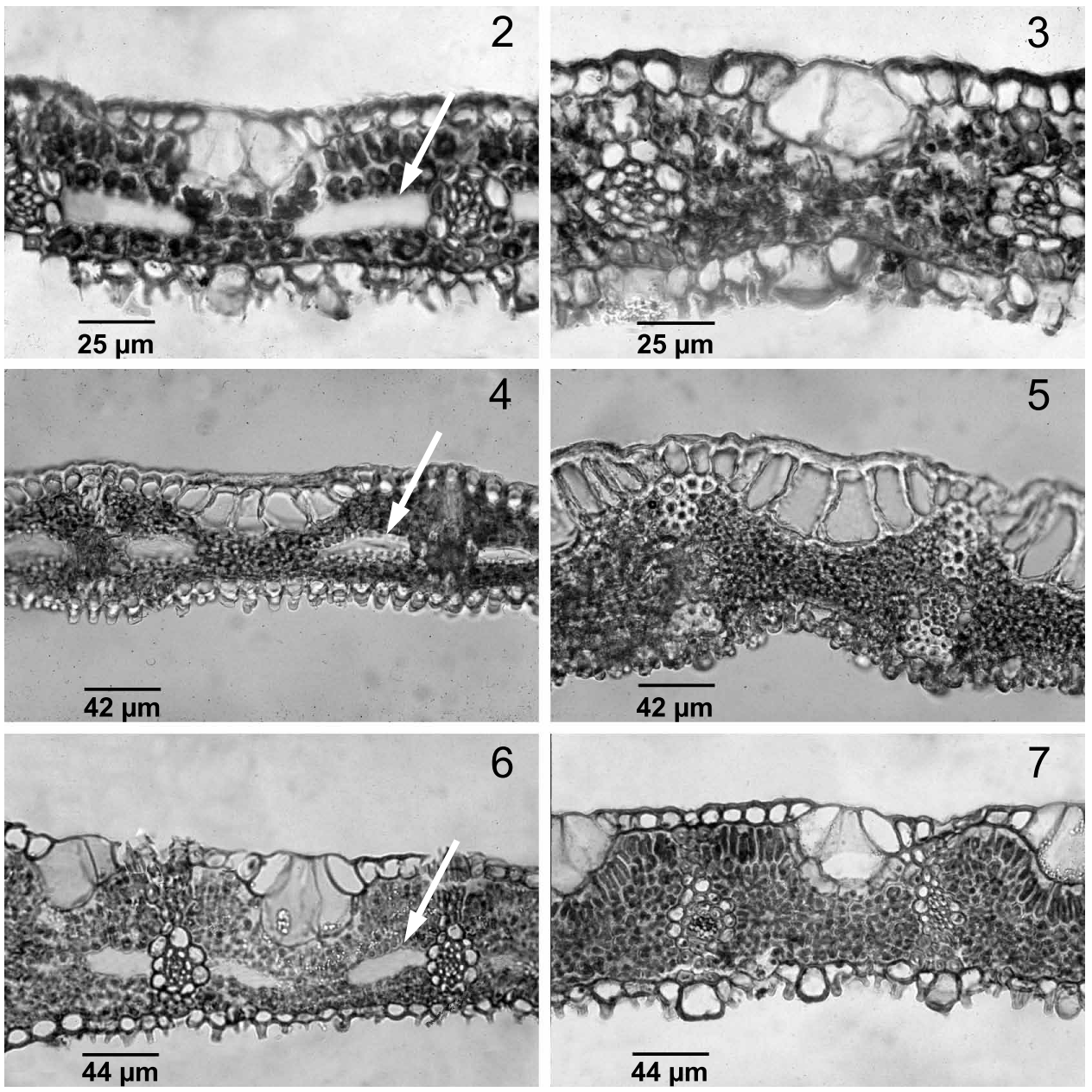

Figs 2-7. Leaf cross sections showing anatomical differences between shade and sun leaves of Yushania niitakayamensis (Figs 2 \& 3), Chusquea culeou (Figs 4 \& 5) and Phyllostachys aurea (Figs $6 \& 7$ ) respectively. 
Leaf Anatomy. Fusoid cells were present in the leaf blades of Y. niitakayamensis and C. culeou collected from shaded environments and from the lower, shaded leaves of the greenhouse-grown P. aurea plant (Figs 2, 4, 6; Table 2). In C. culeou, pairs of fusoid cells developed adjacent to every vein, while in Y. niitakayamensis and P. aurea the fusoid cells tended not to develop in the region nearest the margins. Between the marginal region where fusoid cells did not develop and the mid-leaf region where every fusoid cell developed, fusoid cells were usually either completely developed or completely undeveloped in a mosaic pattern, decreasing in occurrence rather than in size towards the margin. We could not determine from our preparations whether the fusoid cells died and remained intact or whether they uniformly collapsed to form spaces of the same size and shape as mature fusoid cells. Rarely, cells of the same size and in the same position as fusoid cells were observed, but these cells contained chloroplasts and had invaginated walls like the other mesophyll cells (Figs 8 \& 9).
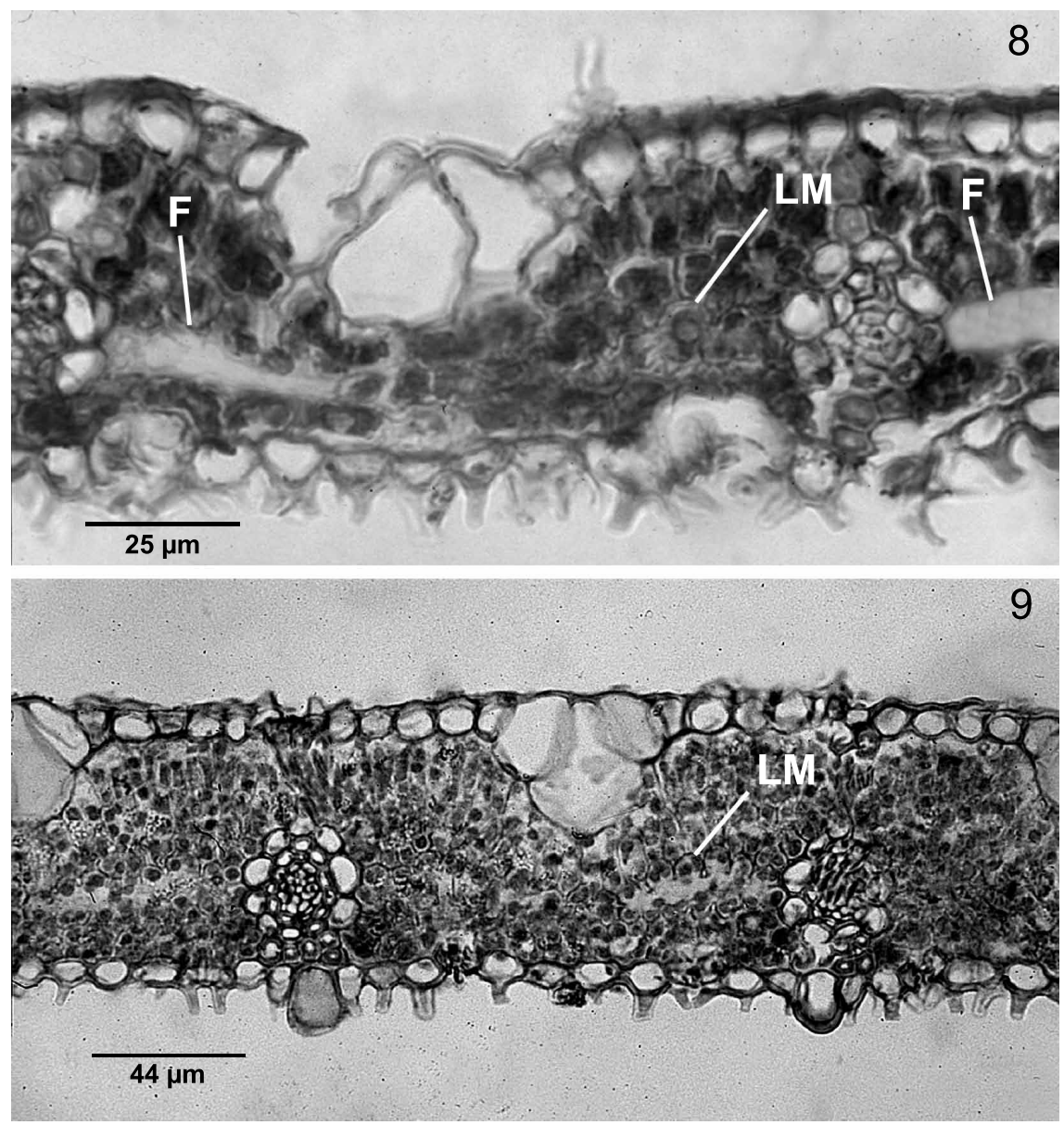

Figs 8 \& 9. Cross sections of shade-grown leaves showing a large mesophyll cell in the position of a fusoid cell. Fig. 8. Yushania niitakayamensis. Fig. 9. Phyllostachys aurea. F = fusoid cell; $\mathrm{LM}=$ large mesophyll cell. 
Fusoid cells were absent from the leaves of Y. niitakayamensis and C. culeou collected from fully sunlit sites and from the upper, exposed leaves of the $P$. aurea plant (Figs $3,5,7)$. No unusually large mesophyll cells were present in the positions of fusoid cells in these leaves. Arm cells in the adaxial-most layer remained asymmetrical but less strongly invaginated than when fusoid cells were present; the remaining mesophyll cells were symmetrically lobed (rosette cells or plicate mesophyll).

The average thickness of foliage leaf blades from plants of Y. niitakayamensis and C. culeou grown under sunny conditions were 62 and $79 \%$ greater, respectively, than those grown under shaded conditions (Table 2). Sun-exposed leaves of $P$. aurea were $30 \%$ thicker than shaded leaves from the same plant. Corresponding with this increased thickness was an increase from three to four or five layers of mesophyll cells. There were also increases in the thickness of the cuticle and both epidermal layers, most dramatically demonstrated in C. culeou (Figs 4 \& 5).

The average distance between minor leaf veins was reduced in sun leaves compared with shade leaves of the same species: 8, 12 and 25\% less for Y. niitakayamensis, P. aurea, and C. culeou, respectively (Table 2). Within each of the three species the number of major veins was more or less constant for both sun and shade leaves. However, the number of minor veins was consistently reduced in the sun leaves.

Infusion experiment. Fresh leaves of Bambusa longispiculata submerged in mineral oil changed from dark green to a notably lighter green as the oil infused into the fusoid cells or the intercellular spaces formed by their collapse (Figs. 10 \& 11). When these fusoid cells (or spaces) were punctured at one end, a bubble of gas was released as the cell filled with oil. Concerted with this gas release and filling of each cell was an obvious further increase in the transmitted light. Over a period of three hours, mineral oil infused into about half of the fusoid cells (or intercellular spaces). Those remaining filled with gas were considerably darker (Fig. 11).

\section{Discussion}

Differences between sun and shade leaves. Consistent differences in leaf morphology and anatomy were observed between sun and shade plants or leaves in Y. niitakayamensis, C. culeou and P. aurea. The smaller leaf size, thicker leaf blades and closer vein spacing found in sun leaves are consistent with findings in other taxa exhibiting sun-shade variation, including the strong negative correlation between mean leaf length and light intensity index observed by Pearson et al. (1994) in C. culeou.

The increased thickness of the sun leaves of $Y$. niitakayamensis and $P$. aurea occurs despite the loss of fusoid cells but is correlated with the occurrence of an additional one or two layers of mesophyll cells as well as increased thicknesses of both epidermal layers and the cuticle. Individual layers of mesophyll cells are also thickened.

Occurrence of fusoid cells. The lack of fusoid cells in the sun leaves of the three species we examined is a dramatic modification of leaf anatomy, making sun and shade leaves appear to come from different species or genera, yet leaves with and without fusoid cells are even found on the same plant (P. aurea). The facultative occurrence of fusoid cells in bamboos has not previously been reported and should be considered when collections or anatomical studies of bamboos are made. This ontological correlation of fusoid cells with shade must be accounted for in any hypothesis of fusoid cell function. 
The large mesophyll cells the size of fusoid cells, which were found in the position of fusoid cells in the zone where fusoid cell development is mosaic, may be intermediates having received a weak or incomplete developmental signal. This suggests that fusoid cells are homologous to mesophyll cells rather than to bundle sheath cells.

The pattern formed by collapsed fusoid cells is almost indistinguishable in clearings and cross sections from that formed by intact fusoid cells (Page 1947; P. Viana, pers. com.), so it is possible that collapse of fusoid cells is the usual condition at functional maturity of the leaf. We may in fact be observing a pattern of regular intercellular spaces formed by the normal collapse of the fusoid cells after they die, but the shape and volume of intact dead cells vs. the intercellular spaces created by their collapse appears to be equivalent and may well not affect the proposed functionality.

Possible function of fusoid cells. The suggestion that fusoid cells may serve as reservoirs for the retention of $\mathrm{CO}_{2}$ from photorespiration (Clark 1991) is inconsistent with the differential occurrence of fusoid cells in shaded environments where photorespiration is less intense. We therefore reject this hypothesis.
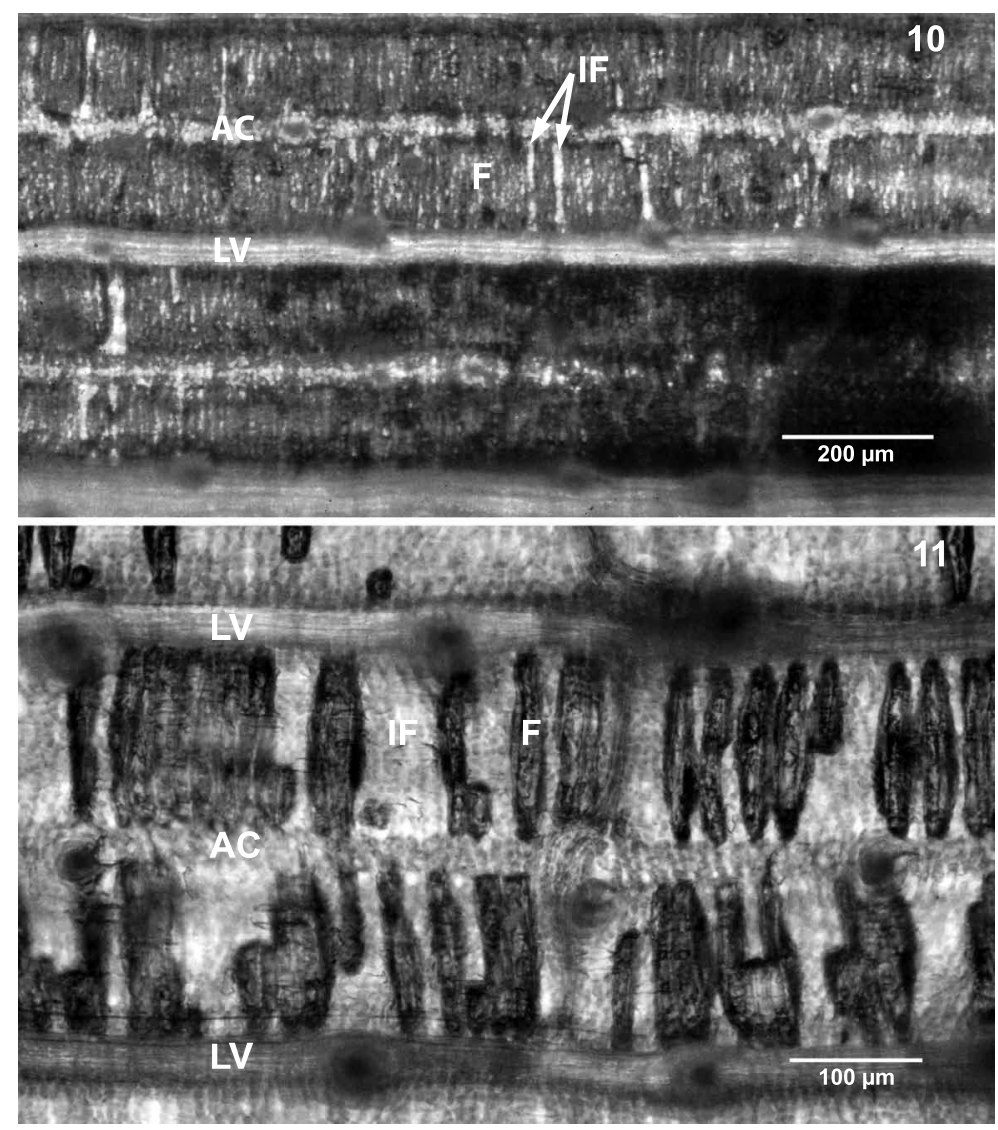

Figs 10 \& 11. Leaf of Bambusa longispiculata infused with mineral oil, viewed from the abaxial side. Infused fusoid cells appear lighter, while uninfused fusoid cells appear darker. Fig. 10. Infusion for 6 minutes. Fig. 11. Infusion for 3 hours. $\mathrm{AC}=$ arm cells; $\mathrm{F}=$ fusoid cell; $\mathrm{IF}=$ infused fusoid cells; $L V=$ leaf vein. 
The difference in refractive index between air and cytoplasm subjects light entering a leaf to intercellular reflection, which can act to trap light within the leaf (Vogelmann 1989, 1993). DeLucia et al. (1996) concluded that intercellular reflectance contributes substantially to the absorption of light and that the increased proportion of spongy mesophyll in shade leaves may increase absorbance. The gas-filled array of fusoid cells (or comparably sized and shaped intercellular spaces) in bamboos may function in a similar way.

Table 2. Comparison of sun and shade leaf anatomy in Y. niitakayamensis, C. culeou, and P. aurea.

\begin{tabular}{|l|l|l|l|}
\hline & Fusoid cells & $\begin{array}{l}\text { Mean Leaf Thickness } \\
(\boldsymbol{\mu m}) \\
(\mathbf{n}=\mathbf{1 0})\end{array}$ & $\begin{array}{l}\text { Mean Vein } \\
\text { Spacing }(\boldsymbol{\mu m}) \\
(\mathbf{n}=\mathbf{1 0})\end{array}$ \\
\hline Yushania niitakaymensis & & & \\
\hline Sun & absent & 97 & 132 \\
\hline Shade & present & 60 & 143 \\
\hline Chusquea culeou & & & 147 \\
\hline Sun & absent & 138 & 197 \\
\hline Shade & present & 77 & \\
\hline Phyllostachys aurea & & & 143 \\
\hline Sun & absent & 119 & 163 \\
\hline Shade & present & 91 & \\
\hline
\end{tabular}

The observed increase in light transmission as fusoid cells (or intercellular spaces) were infiltrated with mineral oil was substantial (Figs 10 \& 11), and indicates increased light absorbance in the native gas-filled state. Although not quantified, this observation is consistent with and lends support to the hypothesis that fusoid cells (or spaces formed by their collapse) contribute to light absorption through a mechanism of intra- or intercellular reflectance. This hypothesis is also supported by the ontological and phylogenetic correlations between fusoid cell occurrence and shade; under shaded conditions where photosynthesis is light-limited, enhanced light absorbance would be advantageous, but under sunny conditions where light is saturating or nearly saturating, enhanced absorbance would be less advantageous or even damaging.

Conclusions. Although this is a preliminary study, the results strongly suggest that fusoid cells function to trap and redistribute light in shade grown leaves of bamboos and, by extension, early-diverging grasses. Developmental studies of fusoid cells are needed to test the proposed homology of fusoid cells to mesophyll cells and also to test whether fusoid cells are indeed empty and dead at maturity and whether their collapse is routine or an artifact of processing. Field studies focused on the functional ecology of sun-shade variation in bamboos would also be of interest. 


\section{Acknowledgments}

Support for field work by RM in Taiwan was provided by the American Bamboo Society, the Pacific Northwest Chapter of the American Bamboo Society, and the Richard and Marjorie Pohl Fund (Iowa State University). Support for field work by LC in Chile was provided by a National Geographic Society Grant to LC and Fernando Zuloaga. Funds for the completion of the work were provided by National Science Foundation Grant DEB-9806877 to LC. RM thanks Dr Chiou Wen-Liang and the Taiwan National Forest Research Institute for logistical support during field work. Christopher D. Tyrrell put the figures in final form. We thank Dr Nels Lersten (Iowa State University) for helpful comments on the manuscript. We are especially grateful to Dr Randy Wayne (Cornell University) for "showing us the light" with respect to the possible function of fusoid cells.

\section{References}

Ashton PMS \& Berlyn GP (1994) A comparison of leaf physiology and anatomy of Quercus (Section Erythrobalanus-Fagaceae) species in different light environments. American Journal of Botany 81: 589-597.

Barbacka M \& van Konijnenburg-van Cittert JHA (1998) Sun and shade leaves in two Jurassic species of pteridosperms. Review of Palaeobotany and Palynology 103: 209-221.

Berlyn GP \& Miksche JP (1976) Botanical microtechnique and cytochemistry. (Iowa State University Press: Ames)

Boardman NK (1977) Comparative photosynthesis of sun and shade plants. Annual Review of Plant Physiology 28: 355-377.

Brandis D (1907) Remarks on the structure of bamboo leaves. Transactions of the Linnean Society of London, Series 2 (Botany) 7: 69-92.

Calderón CE \& Soderstrom TR (1967) Las gramíneas tropicales afines a Olyra L. Atas do Simpósio sôbre a Biota Amazônica (Conselho de Pesquisas, Rio de Janeiro) 4 (Botánica): 67-76.

Chen YF (1989) A review on the origin of Yushan cane and montane grasslands. Yushania 6: 1-26. [In Chinese.]

Chen YF, Lin JY \& Wang CK (1992) Ecological research on high-mountain vegetation in Taiwan (II) - the variation in growth form of Yushan cane. Yushania 9: 117-143. [In Chinese.]

Clark LG (1986) Systematics of Chusquea section Chusquea, section Swallenochloa, section Verticillatae, and section Serpentes (Poaceae: Bambusoideae). (Unpublished PhD thesis: Iowa State University)

Clark LG (1991) The function of fusoid cells in bamboos: An hypothesis. American Journal of Botany 78 (supplement): 22. [Abstract]

Cui M, Vogelmann TC \& Smith WK (1991) Chlorophyll and light gradients in sun and shade leaves of Spinacea oleracea. Plant, Cell and Environment 14: 493-500.

DeLucia EH, Nelson K, Vogelmann TC \& Smith WK (1996) Contribution of intercellular reflectance to photosynthesis in shade leaves. Plant, Cell and Environment 19: 159-170.

Esau K (1977) Anatomy of seed plants, $2^{\text {nd }}$ edition. (Wiley \& Sons: New York)

Grass Phylogeny Working Group (2001) Phylogeny and subfamilial classification of the grasses (Poaceae). Annals of the Missouri Botanical Garden 88: 373-457.

Guala GF (1995) A cladistic analysis and revision of the genus Apoclada (Poaceae: Bambusoideae: Bambusodae). Systematic Botany 20: 207-223.

Guala GF (2003) A new bamboo genus from the cerrados of Brazil. Bamboo Science and Culture 17: $1-3$.

Hsaio JY, Wang BS \& Rieseberg LH (1996) Microgeographic variation in Yushan cane (Yushania niitakayamensis; Poaceae). Plant Species Biology 11: 207-212.

Judziewicz EJ, Clark LG, Londoño X \& Stern MJ (1999) American bamboos. (Smithsonian Institution Press: Washington, D. C.) 
Knapp AK \& Gilliam FS (1985) Response of Andropogon gerardii (Poaceae) to fire-induced high vs. low irradiance environments in tallgrass prairie: Leaf structure and photosynthetic pigments. American Journal of Botany 72: 1668-1671.

Korstian CF (1925) Some ecological effects of shading coniferous nursery stock. Ecology 6: $48-51$.

Lee DW, Bone RA, Tarsis SL \& Storch D (1990) Correlates of leaf optical properties in tropical forest sun and extreme-shade plants. American Journal of Botany 77: 370-380.

Lin W (1978) Bambusoideae, in Flora of Taiwan, vol. 5. (Epoch Publishing Co., Ltd.: Taipei, Taiwan)

Nobel PS (1976) Photosynthetic rates of sun vs. shade leaves in Hyptis emoryi Torr. Plant Physiology 58: 218-223.

Page VM (1947) Leaf anatomy of Streptochaeta and the relation of this genus to the bamboos. Bulletin of the Torrey Botanical Club 47: 232-239.

Pearson AK, Pearson OP \& Gomez IA (1994) Biology of the bamboo Chusquea culeou (Poaceae: Bambusoideae) in southern Argentina. Vegetation 111: 93-126.

Pohl RW (1965) Dissecting equipment and materials for the study of minute plant structures. Rhodora 67: 95-96.

Sass JE (1958) Botanical microtechnique. (Iowa State University Press: Ames)

Soderstrom TR \& Ellis RP (1987) The position of bamboo genera and allies in a system of grass classification. Pp. 225-238 in Soderstrom TR, Hilu KW, Campbell CS \& Barkworth ME (eds) Grass Systematics and Evolution. (Smithsonian Institution Press: Washington, D.C.)

Soderstrom TR, Ellis RP \& Judziewicz EJ (1987) The Phareae and Streptogyneae of Sri Lanka: A morphological-anatomical study. Smithsonian Contributions to Botany 65: 1-27.

Slade BF (1970) The effect of cell elongation on leaf anatomy of Poa alpina. Botanical Gazette 131: 83-95.

Terashima I, Miyazawa S-I \& Hanba YT (2001) Why are sun leaves thicker than shade leaves? Consideration based on analyses of $\mathrm{CO}_{2}$ diffusion in the leaf. Journal of Plant Research 114: 93-105.

Terashima I, Hanba YT, Tazoe Y, Vyas P \& Yano S (2006) Irradiance and phenotype: comparative eco-development of sun and shade leaves in relation to photosynthetic $\mathrm{CO}_{2}$ diffusion. Journal of Experimental Botany 57: 343-354.

Tucker GF \& Emmingham WH (1977) Morphological changes in leaves of residual western hemlock after clear and shelterwood cutting. Forest Science 23: 195-203.

Vogelmann TC (1989) Penetration of light into plants. Photochemistry and Photobiology 50: 895-902.

Vogelmann TC (1993) Plant tissue optics. Annual Review of Plant Physiology and Plant Molecular Biology 44: 231-251.

Watson L \& Dallwitz MJ (1992 onwards) The grass genera of the world: descriptions, illustrations, identification, and information retrieval; including synonyms, morphology, anatomy, physiology, phytochemistry, cytology, classification, pathogens, world and local distribution, and references. Version: 19 March 2010. http://delta-intkey.com.

Woolley JT (1971) Reflectance and transmittance of light by leaves. Plant Physiology 47: 656-662.

Wylie RB (1949) Differences in foliar organization among leaves from four locations in the crown of an isolated tree (Acer platanoides). Proceedings of the Iowa Academy of Science 56: 189-198.

Wylie RB (1951) Principles of foliar organization shown by sun-shade leaves from ten species of deciduous dicotyledonous trees. American Journal of Botany 36: 355-361.

Yano S \& Terashima I (2004) Developmental process in sun and shade leaves of Chenopodium album L. Plant, Cell and Environment 27: 781-793.

Zuloaga FO, Morrone O \& Judziewicz EJ (1993) Endemic herbaceous bamboo genera of Cuba. Annals of the Missouri Botanical Garden 80: 846-861. 